\title{
Opowieść reżysera, który chce być reżyserowany
}

PIOTR PŁAWUSZEWSKI

Dogmaty, czyli co jest dla mnie [Jacka Bławuta - P.P.] najważniejsze:

1. Nie wybieram tematu czy bohatera, jeżeli jest mi on obojętny

2. Wyjmuję kamerę tylko wtedy, gdy czuję, że mam na to zgodę bohatera filmu

3. Nie naprawiam świata jego kosztem

4. Staram się być dyskretny

5. Żeby coś dostać, muszę również dużo dać

6. Staram się być cierpliwy

7. Wyłączam kamerę, kiedy czuję, że sytuacja jest niezręczna dla bohatera

8. Nie nadużywam zaufania bohatera

9. Myślę o tym, co go spotka po filmie

10. Robię filmy, żeby innym sprawiać radość, przywracać nadzieję

Mam za sobą pierwsze akapity książki Jacka Bławuta. Czytam dalej i dalej, coraz bardziej upewniając się, że wiara polskiego twórcy w dokument (daleka od naiwności) sięga znacznie głębiej, niż sądziłem przed rozpoczęciem lektury. Po ostatnich zdaniach już wiem - swą książką wykonuje Jacek Bławut przed kinem dokumentalnym gest ukłonu. A jeśli dodam, iż niektóre fragmenty sprawiają wrażenie wyjętych z bardzo osobistego notatnika, to wcale nie narażę się na zarzut przesady.

Wierzę, że nie idę za daleko w swym czytaniu tej niewielkiej objętościowo książki, gdy jej tytuł próbuję rozumieć w nieco szerszym sensie niż tylko ten bezpośrednio sugerowany przez słowa: bohater w filmie dokumentalnym. Czy aby nie jest nim również sam autor? Mocno zagnieździło się we mnie przekonanie, że w równym stopniu napisał Jacek Bławut książkę o swoich bohaterach, co o sobie samym. Gdzie zatem słowa „autor-reżyser”? -

[1] J. Bławut, Bohater w filmie dokumentalnym. Koncepcja autorska, Łódź 2010 (ten i kolejne cytaty z książki Jacka Bławuta lokalizuję przez podanie numeru strony w nawiasie, umieszczonym bezpośrednio za przytoczeniem). zastanawiałem się. Aż w końcu przykuł moją uwagę fragment pewnego akapitu:

Ja czerwienię się, kiedy ktoś nazywa mnie reżyserem. Czuję się zażenowany, kiedy ktoś przy mnie mówi, że jest reżyserem, albo szczyci się tym, że reżyseruje filmy. Dla mnie to jest strasznie wstydliwa sprawa. Co to znaczy być reżyserem? To znaczy mówić komuś, gdzie ma stanąć?

Straszne. Reżyseria... Nie rozumiem, co znaczy to słowo (s. 15)[1].

Znacznie większa już doza pewności cechuje zaś Jacka Bławuta, gdy wielokrotnie powraca w swym pisaniu do zjawiska niebywałej transakcji, jaka potrafi/ powinna przydarzyć się na linii autor-bohater (patrz - dogmat nr 5).

Naraz stało się dla mnie niemal oczywiste, że ów bohater $w$ filmie dokumentalnym to zarówno alkoholik Michał Waluda, więzień Robert Jurczyga, kick boxer Marek Piotrowski, jak i... dokumentalista Jacek Bławut. Wyznaje otwarcie ten ostatni:

Jeśli robi się film i nic się nie daje, zadaje tylko pytania, to wtedy najzwyczajniej w świecie wykorzystuje się człowieka na potrzeby filmu. I tyle, nic więcej (s. 9).

Co zatem daje twórca, a czym obdarowuje bohater? Gdzie się krzyżują ich spojrzenia?

Kilka fragmentów narracji daje do myślenia w sposób szczególny. „Każdy kolejny dokument czy fabuła to próg. To szansa na przekroczenie jakiejś granicy, a przekraczanie granic to rozwój” (s. 8). Identyczne wyznanie (z odpowiednio podmienionymi słowami: dokument i fabuła) mogłoby zrodzić się w ustach niejednego z filmowych bohaterów Bławuta. Ta sama obawa przed usypiającym wyhamowaniem zdaje się jednoczyć postaci z różnych planet: doświadczonego reżysera, szalonego w sportowych wyczynach motorowodniaka (to o Waldemarze Marszałku ze Ślizgiem do nieba, 1985) czy pokaranego za patriotyczną brawurę Kazimierza Leskiego 
(Byłem generałem Wehrmachtu, 1988), który w obawie przed regresem pobudzał swój umysł do intelektualnej pracy nawet w kaźni stalinowskiego więzienia.

Szczególny status Bławuta-reżysera ma swe kolejne źródło we wspomnianej już zasadzie wzajemności - by coś od bohatera otrzymać, trzeba się nim po części samemu stać. Pisze autor:

To ja jestem manipulowany, to ja chcę być reżyserowany. Świetnie się czuję, kiedy widzę, że bohater ma wielką frajdę, kiedy odkrywa przede mną swoje barwy, uwodzi mnie, a ja się daję temu ponieść" (s.15).

Natychmiast przychodzi na myśl Wieńczysław Gliński, który - jak się okazało - niedługo przed śmiercią poprosił Jacka Bławuta na planie jego fabularnego debiutu Jeszcze nie wieczór (2008) o rzecz szczególną, bo o szansę na spełnienie aktorskiego marzenia. „No to mówię: «słuchaj, mamy tu Fausta, ale jak masz marzenie zagrać Hamleta, to proszę bardzo, graj sobie Hamleta»" (s. 98). Kto reżyserem, kto bohaterem tej opowieści?

\section{Autor}

Mimo wielu przemyśleń zdających się mieć wydźwięk uniwersalnego prawidła, bez wątpienia pozostaje książka Jacka Bławuta prywatną historią/teorią własnego kina, historią pisaną w pierwszej osobie liczby pojedynczej. Jeśli jest miejsce na dogmaty, to $\mathrm{z}$ ważnym dla ich odbioru dopiskiem: „czyli co jest dla mnie najważniejsze" (pogr. - P.P.). Dochodzi do tego (co mniej oczywiste w tym kontekście) aspekt stricte pisarski Bohatera $w$ filmie dokumentalnym - brawa dla redaktora i korektora tomu, jeśli to ich decyzją zachowany został styl tych akapitów, które określić mógłbym "gadanymi” - w jak najlepszym sensie. Słyszy się wtedy kolejne zdania, ale też żywo rozentuzjazmowany głos, nierzadko głowiący się nad dobraniem właściwych słów. Można to uładzić, łatwo uczynić przezroczystym i bardziej w swym brzmieniu kategorycznym, jednak siła wywodu Bławuta między innymi na tym przyznawaniu się do wahań polega.
Jest taka chwila, nie mam słowa na to dobrego, ale chodzi o to, że czuję w drugiej osobie zaufanie i wtedy ona mówi: „słuchaj, zrobimy film, ja ci opowiem historię, a ty ją pięknie nakręcisz [...]" (s. 14)

- oto próbka owej poetyki żywego słowa, które staje wobec jednej z tajemnic dokumentu: gdy waży się decyzja, czy wolno już uruchomić kamerę.

Konsekwentnie przekonuje czytelnika Jacek Bławut, że jego myślenie o filmie dokumentalnym sięga zawsze poza czysto artystyczną satysfakcję z dobrze zrealizowanego zadania. Zaczyna się wszystko od zasianego w twórcy ziarna ciekawości (patrz - dogmat nr 1), by bardzo często zaowocować chęcią wpłynięcia swym dziełem na pozazdjęciową już rzeczywistość - stąd choćby zamierzenie, by za sprawą Nienormalnych (1990) „dodać odwagi rodzicom dzieci upośledzonych” (s. 45), stąd wyrażana w każdym odcinku przez jednego z bohaterów cyklu Ja, alkoholik (2003) wiara, że wpłynie on (ów cykl) na społeczne podejście do choroby alkoholizmu. I choć najczęściej otwierać odbiorcze oko chce Bławut za pomocą opowieści o wznoszącym się natężeniu nadziei i podnoszących na duchu (patrz - dogmat nr 10), to może tym bardziej wybija się na tekstową niepodległość fragment książki dotyczący wstrząsającej Kostki cukru (1986), w którym sformułowane zostaje znamienne wyznanie: „Kostka cukru jest dla mnie tęsknotą za czystą formą i jedynym filmem skierowanym przeciw nam, ludziom" (s. 78). Sporo znaczą te słowa, jak mi się przynajmniej zdaje, nie tylko w kontekście bezpośredniego ich użycia - bo nasuwającym się po lekturze Bohatera $w$ filmie dokumentalnym wnioskiem nie do zlekceważenia byłby ten, który każe kino Jacka Bławuta nazwać wytrwale trwającym „przy człowieku”. Bez chodzenia na skróty: bo to często człowiek niczego nieułatwiający, z ciążącym potencjałem, by wzbudzać podejrzliwość, nie zaciekawienie. Czasami jednak i on ma szczęście trafić na kogoś, kto pisze w swej książce:

Dla mnie każdy człowiek jest cudem. Każdy sam w sobie jest czymś niebywałym, jakkolwiek by na 
to patrzeć, jakikolwiek by był. Najciekawsze w robieniu filmów jest dla mnie właśnie spotkanie z nim" (s. 10).

Jak bardzo wymykają się te słowa zarzutowi o naiwność, wie każdy, kto zetknął się choćby z dokumentem Born Dead (2004).

\section{Bohater}

Centrum tego wszechświata. Przedmiot reżyserskiej pasji, troski i nadziei. Swemu bohaterowi - zgodnie z tytułową obietnicą - poświęca Jacek Bławut w książce najwięcej autorskiej uwagi. Rzecz to fascynująca nie tylko jednak ze względu na same postaci, z którymi pierwszy kontakt zapewniły nam - widzom - dokumentalne dzieła $z$ trzech ostatnich dekad. Opowieść o nich szybko i dyskretnie rozszerza swe ramy, okazując się przyspieszonym kursem filmowej dokumentalistyki najwyższej próby. Kurs - szybko dodam - nie jest łatwy, a poważne przemyślenie jego kolejnych przystanków tylko to przekonanie pogłębia. A jednak. A jednak chciałoby się w tym miejscu sparafrazować zakończenie recenzji filmu Duże zwierzę Jerzego Stuhra, w której Tadeusz Lubelski przyznał, że projekcja wzbudziła w nim niespodziewaną dość chęć posiadania wielbłąda. Tak i ja, w trakcie czytania książki Jacka Bławuta, odnalazłem w sobie więcej niż chęć zostania dokumentalistą. Kto inny w takim stopniu wykształca w sobie tajemną sztukę docierania do drugiego człowieka - do swego bohatera?

Nie w zaskakującej odkrywczości leży siła narracji Bławuta. Recepty zapewniające udaną komunikację międzyludzką wydają się na tyle oczywiste, że aż w swej oczywistości podejrzane. Słuchaj - bądź cierpliwy - przystań - zaufaj - poczekaj na zaufanie - nie wykorzystuj - myśl o konsekwencjach. Zasługiwałby ten szlachetny kodeks na niewiele więcej niż kurtuazyjną akceptację, gdyby nie szło za nim na kartach Bohatera $w$ filmie dokumentalnym nazwę to w niedoskonały sposób - „samo życie”. W jego żywiole, często brutalnym i szorstkim w dotyku, łatwo o zdemaskowanie najlepiej nawet brzmiących prawideł. Mam mocne przekonanie, że Bławut-reżyser nigdy sobie niczego w tym względzie nie ułatwiał. Robił przecież i robi nadal filmy o tych, których kamera nie zrozumie w ciągu czterech dni zdjęciowych. Kiedy na własny użytek, zerkając na notatki z lektury i filmografię twórcy Superciężkiego, spróbowałem skonstruować modelowego jej bohatera, okazał się on (w całym swym uproszczeniu) zaopatrzony w trzy podstawowe wyróżniki:

1 - to osoba w trudnym (jakże banalnie i nieadekwatnie to brzmi...) egzystencjalnie położeniu, obarczona ciężarem wrodzonym (np. niepełnosprawni umysłowo z Nienormalnych) lub w mniej lub bardziej zawiniony sposób nabytym (np. kaleki żołnierz Legii Cudzoziemskiej z Rogatych dusz (1995), ale też Michał-alkoholik ze Szczura w koronie (2005): „Geny mają wpływ. To jest bardzo skomplikowane. Wszystko to się często nakłada” (s. 32) - pisze o swym bohaterze Bławut).

2 - to osoba $\mathrm{z}$ owym ciężarem próbująca żyć/uporać się. Patrząc z dystansu, wydaje się ta sytuacja konstytuować filmowy świat reżysera. On sam wyznaje:

Dochodzę do wniosku, że najbardziej ciekawi mnie człowiek w tych momentach życia, w których musi walczyć, pokonywać swoje słabości i w których musi dokonywać wielkich czynów, żeby żyć. Bo kiedy walczy on ze swoimi ułomnościami, to naprawdę widać jego wielkość (s. 13).

Kto wie, czy najbardziej dojmującym ucieleśnieniem tego zmagania nie jest Marek Piotrowski, czyli tytułowy Wojownik. Wyniki badań jego mózgu zdają się bezlitosne - on sam z kolei konsekwentnie je ignoruje, wierząc w powrót do całkowitej sprawności. Po której stronie barykady ustawia swą kamerę Jacek Bławut?

Miałem mu tę nadzieję zabrać? Pozbawić go sił do dalszej walki? Walki o zdrowie, może życie? [...] Dla filmu może byłoby to i dobre, ale dla mnie film to tylko film" (s. 42).

3 - to osoba, która zepchnięta została na margines społecznej świadomości, gdzie zazwyczaj natyka się na mur niechęci czy braku zaufania, a najlepsze, co może ją spotkać, to 
milcząca obojętność. Stąd jasno wyłożona motywacja autorska w kontekście Nienormalnych:

Chciałem tym filmem dodać odwagi rodzicom dzieci upośledzonych, żeby nie przemykali bocznymi bramami, żeby mogli pójść ze swoim dzieckiem do kawiarni (s. 45).

Jest wreszcie Robert z Born Dead, więzień spełniający wszelkie warunki, by w momencie przypadkowego spotkania zejść mu z drogi i udać, że nie istnieje(my). Mija kilkadziesiąt minut filmu i - wypada się zawstydzić. Nic tu, rzecz jasna, z łatwego i naiwnego pocieszenia. To tylko: słuchaj - bądź cierpliwy przystań - ...
Ostatnie kilka minut Szczura w koronie, scena w pokoju rozświetlonym tylko świeczką. Dla piszącego te słowa - najpiękniejszy fragment dotychczasowej filmowej drogi Jacka Bławuta. Mając ów fragment w pamięci, docieram na skraj książkowego podsumowania. Dziesiąty dogmat napełnia się po brzegi treścią. Można nie chcieć być dokumentalistą? Takim dokumentalistą.

Rec.: Jacek Bławut, Bohater w filmie dokumentalnym, Wydawnictwo Państwowej Wyższej Szkoły Filmowej, Telewizyjnej i Teatralnej, Łódź 2010.

\section{Adoracja aberracji}

\section{GRZEGORZ TORZECKI}

Rozpanoszyła nam się tzw. sztuka nowych mediów. Nie tylko w Internecie, galeriach, muzeach czy czasopismach, ale wspięła się także na uniwersyteckie katedry, zdobywając gorliwych apologetów, którzy znalazłszy swoją niszę, wdarli się na Olimp Nauki i świeżo odkrytą terra incognita uprawiają do utraty tchu.

Aby zaś nie strącił ich stamtąd okrzyk jakiegoś dziecka: „król jest nagi” (wszak pup i dup, siusiaków i kutasów wśród tych dzieł jest bez liku), stworzono cały nowy metajęzyk dla opisania tego zjawiska. Oto jego próbka:

Stwierdza on bowiem, że opowiada się za ergodycznością a przeciw interaktywności jedynie ze względu na dostrzegane przez niego w tej pierwszej większe możliwości analityczne oraz jej mniejszą dychotomiczność.

\section{I dalej:}

Wszystkie powyższe kwalifikacje i dystynkcje przypisywane interakcjom przez interakcjonizm symboliczny dają się z pożytkiem zastosować przy analizie także i tych interakcji, które funduję sztukę interaktywną. (Ryszard W. Kluszczyński, Sztuka interaktywna, 2010)
Ale to jeszcze nic w porównaniu z tym, co usiłował wyrazić inny znakomity myśliciel, pisząc, że kultura audiowizualna to:

[...] wyraz seksualnych popędów cząstkowych, które uniknęły prymatu genitalnego na drodze subwersywnego zdobycia cząstkowych obsadzeń obiektu przez libido dzięki imaginatywnym uniwersalizowaniom się podmiotu widza w ogólnoludzkiej współczulnej tendencji projekcyjnointrojekcyjnej wymiany duchowych obecności. (Wojciech Chyła, Kultura audiowizualna, 1999)

Kiedy patrzę na utrwalony w komputerze zapis tego cytatu, przed oczami robi mi się czerwono od podkreśleń. A zdawało mi się, że mam najnowocześniejszy edytor tekstów.

Tego rodzaju mowa jest w każdym razie doskonałym rozwiązaniem problemu percepcji sztuki nowych mediów przez publiczność. Dziecku zatkano usta. Jeśli „nie trawi” ono tej „sztuki”, to jest to wyłącznie jego problem. Gorzej, jest to problem związany z niedostatkiem jego edukacji, a nie problem działającego w symbiozie, hermetycznego kręgu wzajemnej adoracji złożonego $\mathrm{z}$ artystów, sponsorów (producentów sprzętu audiowizualnego, oświetleniowego czy komputerowego) oraz 